\title{
W obliczu przemian i nowej rzeczywistości. Sztuka lat 1919-1939 LXVIII Ogólnopolska Sesja Naukowa Stowarzyszenia Historyków Sztuki Łódź, 21-22 listopada 2019 roku
}

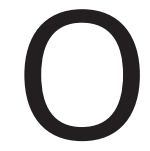

gólnopolskie sesje naukowe organizowane przez Stowarzyszenie Historyków Sztuki mają długą tradycję. W 2019 roku przygotowana została przez Oddział Łódzki SHS ich 68 edycja. Tematyka spotkania poświęcona została zjawiskom w sztuce obejmującym lata 1919-1939. Impulsem do analizy przemian i nowej rzeczywistości, kształtującej sztukę tego okresu, była setna rocznica utworzenia województwa łódzkiego.

Skupieni w Oddziale Łódzkim członkowie stowarzyszenia od blisko 50 lat popularyzują wiedzę o spuściźnie kulturowej tego ośrodka, organizując m.in. prelekcje i konferencje, których pokłosiem stała się seria wydawnicza "Sztuka w Łodzi”. W dotychczasowych wydaniach badacze w przeważającej mierze analizowali architekturę, malarstwo i rzemiosło artystyczne XIX i początku XX wieku. W ciągu kilku ostatnich lat widoczny jest duży wzrost zainteresowania szeroko rozumianą spuścizną okresu modernizmu, socrealizmu i okresu PRL. „Odpowiedni” dystans czasowy, następująca zmiana pokoleniowa, sprzyjają nowym perspektywom

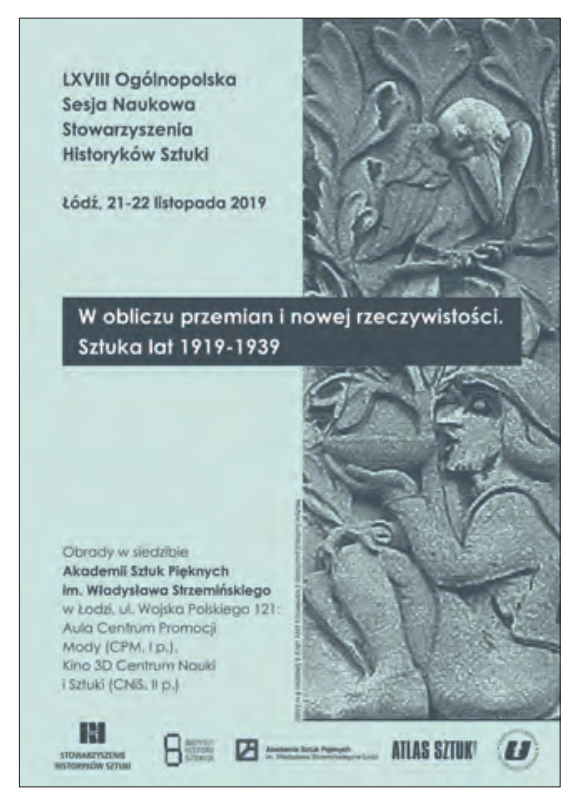

1. Plakat LXVIII Ogólnopolskiej Sesji Naukowej Stowarzyszenia Historyków Sztuki, proj. Jacek Wilk, 2019 


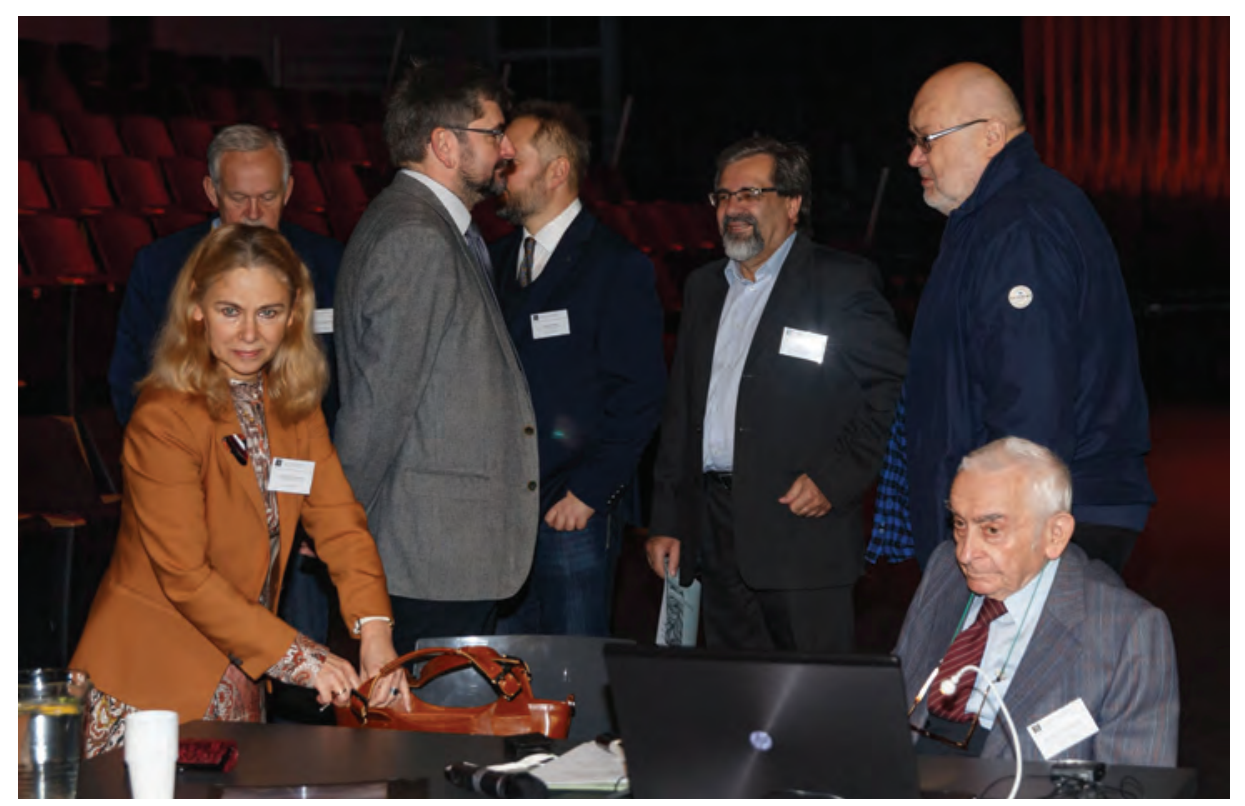

2. Członkowie Stowarzyszenia Historyków Sztuki. Na pierwszym planie od lewej: prof. Irena Kossowska, prof. Andrzej K. Olszewski; na drugim planie od lewej: prof. Wojciech Włodarczyk, prof. Piotr Gryglewski, dr Łukasz M. Sadowski, prof. Krzysztof Stefański, prof. Lechosław Lameński.

Fot. Jarosław Darnowski CPM/ASP, 2019

badawczym. Łódzki Odział SHS zaproponował w podejmowanej problematyce sesji ponowienie refleksji nad zjawiskami występującymi w sztuce lat 1919-1939: zderzeniem tradycji z poszukiwaniem nowych form wyrazu artystycznego, relacją sztuka-państwo, sztuka-społeczeństwo. Dynamiczna zmiana wizerunku miast II Rzeczypospolitej, wynikająca z dokonującej się po I wojnie światowej transformacji polityczno-kulturowej, stała się polem do szerokich rozważań badaczy z różnych ośrodków naukowych z Polski i zagranicy.

Zaproponowany temat spotkał się z pozytywnym odbiorem środowiska historyków sztuki, czego dowodem był bogaty program sesji, obejmujący 31 wystąpień badaczy z 25 ośrodków naukowych i instytucji kultury z Polski, Rosji i Ukrainy. Obrady prowadzone były w dniach 21-22 listopada w pomieszczeniach Akademii Sztuk Pięknych im. Władysława Strzemińskiego w Łodzi. Realizację tego spotkania koordynował komitet organizacyjny w składzie: dr Łukasz M. Sadowski, Małgorzata Wróblewska Markiewicz, Agnieszka Lorenc-Karczewska i autorka niniejszego tekstu. Przychylności i wsparcia całemu przedsięwzięciu udzielili: Zarząd Główny SHS - reprezentowany przez prezesa prof. Wojciecha Włodarczyka, rektor ASP w Łodzi - prof. Jolanta Rudzka-Habisiak, dyrektor Instytutu Historii Sztuki Uniwersytetu Łódzkiego - prof. Piotr Gryglewski oraz „Atlas Sztuki”. Członkowie komitetu OŁ SHS podczas organizacji sesji zawsze mogli liczyć na pomoc i radę kierującej Biurem Zarządu Głównego SHS Ewy Staszewskiej. 


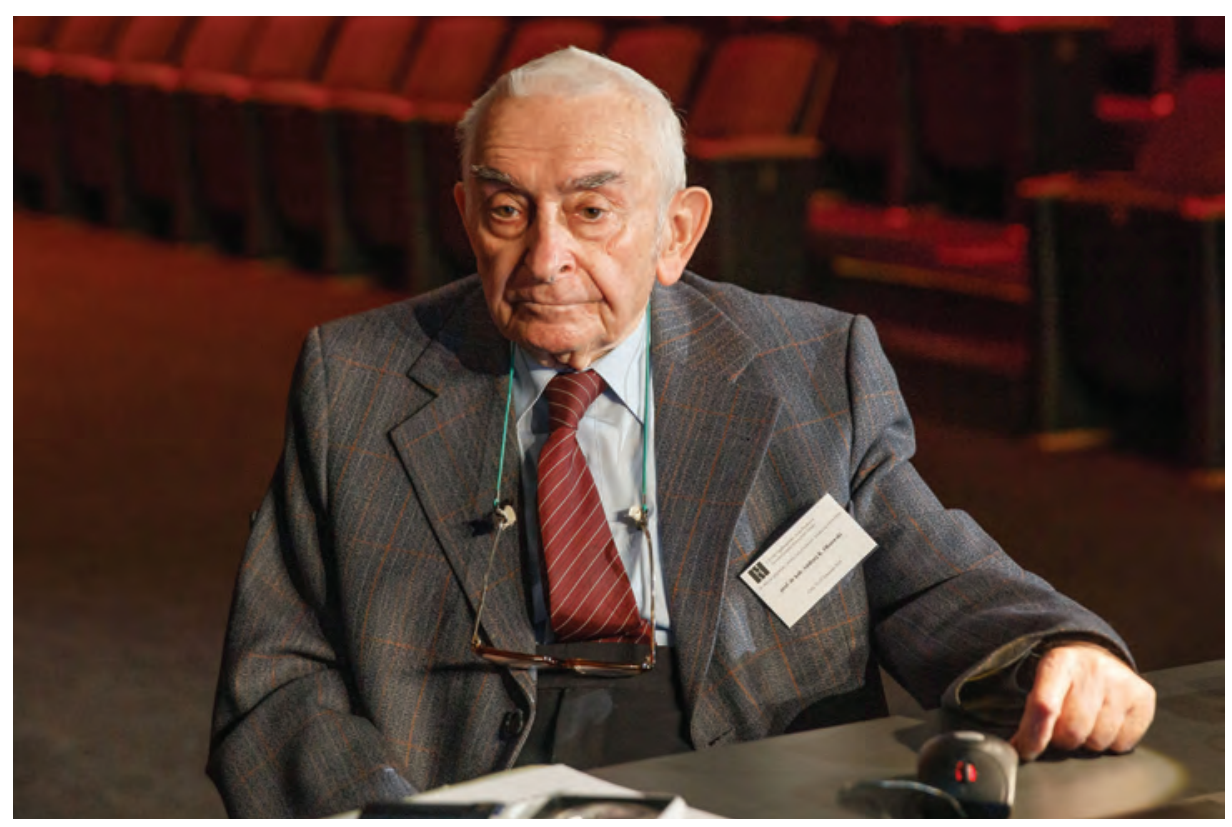

3. Prof. Andrzej K. Olszewski. Fot. Jarosław Darnowski CPM/ASP, 2019

Pierwszy dzień spotkania zgromadził w Auli Centrum Promocji Mody ponad 200 osób zainteresowanych prezentowaną tematyką. Sesję inaugurował referat prof. Andrzeja K. Olszewskiego, który podzielił się refleksjami i spostrzeżeniami nad rozwojem badań nad sztuką okresu dwudziestolecia międzywojennego. Dopełnieniem tej części było wystąpienie prof. Ireny Kossowskiej, akcentujące dotychczas niepodejmowane wątki w postawie artysty, krytyka sztuki Tadeusza Pruszkowskiego. W kolejnej części prezentowane były referaty profesorów Michała Pszczółkowskiego i Jakuba Lewickiego oraz doktorów Inny Abramiuk i siostry urszulanki Anny Tajszerskiej, poruszające złożoną problematykę kierunków twórczych $w$ architekturze, z jednej strony zmierzającej ku nowoczesności, z drugiej podejmującej dyskurs z tradycją.

Kolejne trzy wystąpienia prezentowali przedstawiciele łódzkiego środowiska naukowego. Prof. Krzysztof Stefański rozwinął problematykę luksusowych kamienic czynszowych o modernistycznych formach w znaczących ośrodkach miejskich II Rzeczypospolitej. Prof. Piotr Gryglewski w swoich dociekaniach skupił się na sposobie postrzegania zabytków województwa łódzkiego w ramach poszukiwania tożsamości narodowej. Dr Agata Wereszczyńska przedstawiła wyniki prowadzonych przez siebie badań nad międzywojenną twórczością Władysława Sowickiego - architekta, projektanta wnętrz i mebli. Referat ten zapowiadał zmianę tematyki wystąpień z części poświęconej dotychczas architekturze ku analizie zjawisk $\mathrm{w}$ malarstwie i teorii sztuki. 


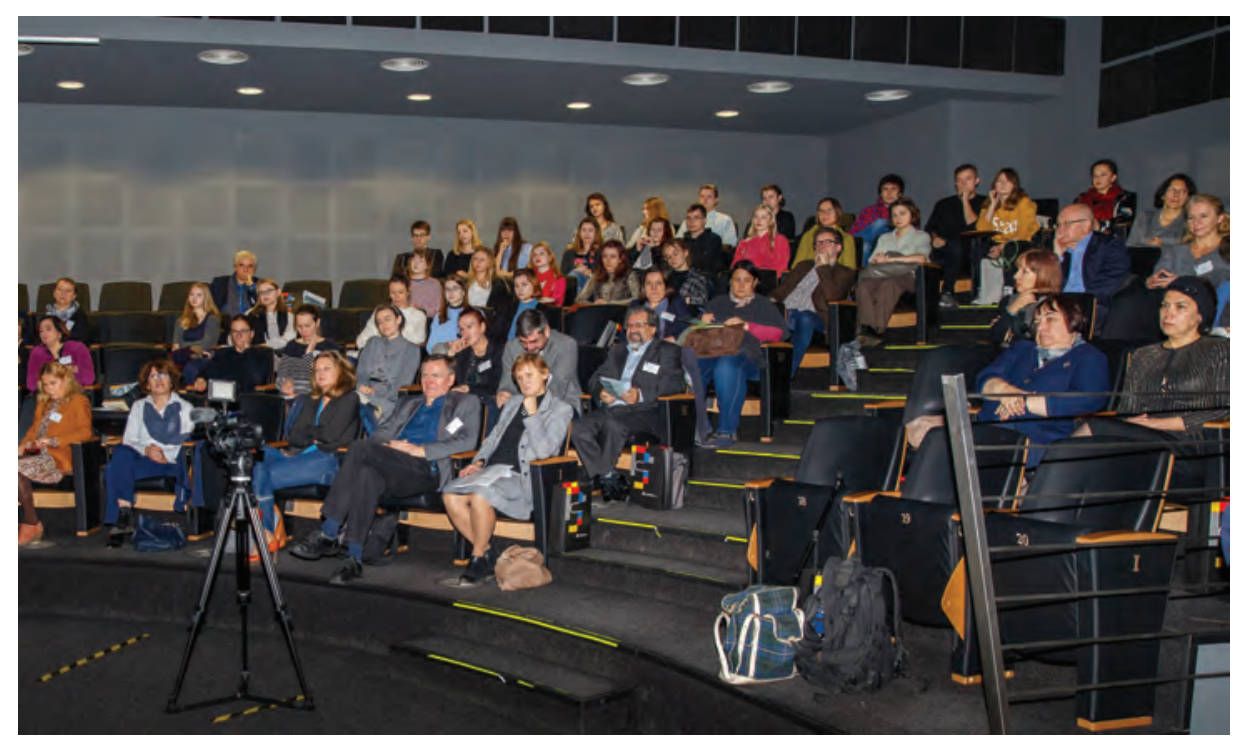

4. Uczestnicy sesji podczas obrad. Fot. Jarosław Darnowski CPM/ASP, 2019

Referat prof. Józefa Tarnowskiego pt. Geneza zwrotu antynaturalistycznego $w$ polskim malarstwie okresu międzywojnia rozpoczął kolejny panel. Agnieszka Janczyk zaprezentowała prace zespołu dekorującego sale Zamku Wawelskiego w latach 1925-1939 pod kierownictwem Adolfa Szyszko-Bohusza. Wioletta Pieńkowska-Kmiecik przedstawiła pracę Augusta Zamoyskiego i Bolesława Cybisa pt. Polskie niebo, zrealizowaną w Gimnazjum Polskim w Gdańsku. Klamrą spinającą panel było wystąpienie Łukasza Rozmarynowskiego zatytułowane Leon Chwistek artysta a Polska Szkoła Matematyczna, po którym nastąpiła część dyskusyjna.

Pierwszy dzień obrad zamknęło ogłoszenie wyników i rozdanie nagród laureatom konkursów Stowarzyszenia Historyków Sztuki im. ks. prof. Szczęsnego Dettloffa i im. prof. Jerzego Łozińskiego. Ci słuchacze i referenci, dla których czas przewidziany na dyskusję okazał się niewystarczający, mogli kontynuować rozważania na wieczornym spotkaniu w holu Centrum Promocji Mody.

Drugi dzień sesji prowadzony był symultanicznie w dwóch salach. W Auli Centrum Promocji Mody pierwszy panel otworzyło wystąpienie dr Ewy Rybałt pt. Polacy, Żydzi, Ukraińcy - wokól lwowskiej grupy „Artes”. Następnie głos zabrała dr Aneta Borowik, prezentująca uwarunkowania polityczne i ekonomiczno-prawne powstającej na terenie Górnego Śląska architektury. Po krótkiej przerwie kawowej kolejną część obrad rozpoczęła prof. Lejła Chasjanowa referatem zatytułowanym Reewakuacja mienia polskiego z Rosji 1919-1921. Następnie głos zabrała Monika Kuhnke, poruszając zagadnienie Architektura i sztuka w stużbie polskiej dyplomacji w latach 1918-1939. Panel zamykało wystąpienie dr. Błażeja Ciarkowskiego pt. Jak budowano 
„Polskę śródziemnomorską". Architektoniczne związki II Rzeczypospolitej i faszystowskiej Italii. Kolejną część sesji rozpoczęła analiza Eleny Yakhnenko poświęcona nowemu spojrzeniu na pojawiające się tendencje w plakatach $z$ lat 20. i 30. w Polsce i Rosji. Prof. Piotr Fiuk rozszerzając tematykę międzynarodowych wpływów artystycznych, skoncentrował się na problematyce modernizacji miast historycznych.

W Kinie 3D Centrum Nauki i Sztuki omówione zostały Wyzwania nowoczesności. Kobiety - artystki w międzywojennej Łodzi prezentowane przez Izabellę Powalską. Kolejne wystąpienie omawiające artystyczną działalność kawiarni Instytutu Propagandy Sztuki w Warszawie zaprezentowała dr Magdalena Kasa. Następny panel poświęcony zagadnieniom ekspozycji sztuki zaprezentowały: Anna Kroplewska-Gajewska (Muzeum Okręgowe w Toruniu), Barbara Chojnacka (Muzeum Okręgowe im. Leona Wyczółkowskiego w Bydgoszczy) i Elżbieta Fuchs (wieloletni dyrektor Miejskiej Galerii Sztuki w Łodzi). Ostatni panel otworzyło wystąpienie prof. Eleonory Jedlińskiej o symboliczności portretu Neue Sachlichkeit. Dr Katarzyna Nowakowska-Sito analizowała dylematy różnorodnych postaw artystycznych lat 30. pojawiające się na forum działalności Instytutu Propagandy Sztuki. Rozważania prof. Anety Pawłowskiej nad Inspiracją sztuką Czarnej Afryki w polskiej sztuce okresu międzywojennego zamknęły tę część panelu.

Na zakończenie dwudniowych obrad zgromadzeni mogli wysłuchać referatów poświęconych środowisku artystycznemu Łodzi, gdzie działalność grupy „Start” prezentowały dr Irmina Gadowska i dr Agnieszka Świętosławska; Monika Nowakowska przybliżyła sylwetkę Wacława Dobrowolskiego - portrecisty łodzian, a Adam Drozdowski przedstawił kształtowanie się wizerunku nowoczesnej kobiety w Łodzi w latach 30. XX wieku.

Różnorodna tematyka prezentowanych referatów spotkała się z pozytywnym oddźwiękiem, na co wskazywała duża liczba odbiorców i ożywione dyskusje. Szeroko ujęty temat dał pole do rozważań nad ciągle odkrywaną i badaną sztuką okresu dwudziestolecia międzywojennego. Nowe perspektywy, nowe konteksty i ujęcia problemu prezentowane przez referentów znajdą swoje odzwierciedlenie w opracowywanej publikacji Oddziału Łódzkiego Stowarzyszenia Historyków Sztuki. 